\title{
PERBANDINGAN PEMAHAMAN KONSEP EKSTRAPOLASI ANTARA METODE PEMBELAJARAN INKUIRI TERBIMBING DAN INKUIRI BEBAS TERMODIFIKASI
}

\author{
Jusman $^{1}$, Hajeriati ${ }^{2}$ \\ Jurusan Pendidikan Fisika, Fakultas Tarbiyah dan Keguruan, UIN Alauddin Makassar, \\ jusmanjilc@yahoo.co.id
}

\begin{abstract}
The purpose of this study was to determine the comparison of extrapolation understanding between students taught by using Modified Free Inquiry Learning and Guided Inquiry Motodes at Physics Education Department, UIN Alauddin Makassar. The sample was selected by simple random sampling technique. The instrument of data collection used was an extrapolation understanding test, with descriptive data analysis and inferential statistics techniques namely independent sample T-2 test. Based on these using descriptive statistics was obtained the extrapolation understanding test results through Modified Free Inquiry Learning and Guided Inquiry Motodes on Students' Physics Education that was categorized in average. Furthermore, the inferential statistics stated that $t_{\text {count }}>t_{\text {table was }} 3,12>1,98$ in which $\mathrm{H} 0$ was rejected. These showed that there was the difference in the understanding of extrapolation between Modified Free Inquiry Learning and Guided Inquiry Motodes on Students' Physics Education, UIN Alauddin Makassar.
\end{abstract}

Keywords : extrapolation understanding, guided inquiry, modified free inquiry.

\begin{abstract}
Abstrak : Tujuan penelitian ini adalah untuk mengetahui perbandingan pemahaman ekstrapolasi antara mahasiswa yang diajar dengan menggunakan motode pembelajaran inkuiri bebas termodifikasi dengan motode inkuiri terbimbing pada Jurusan Pendidikan Fisika UIN Alauddin Makassar. Pemilihan sampel melalui teknik simple random sampling. Instrument pengumpulan data yang digunakan adalah tes pemahaman ekstrapolasi, dengan teknik analisis data statistik deskriptif dan statistik inferensial yaitu uji T-2 sample independent. Berdasarkan hasil analisis data menggunakan statistik deskriptif diperoleh hasil tes pemahaman ekstrapolasi dengan menggunakan inkuiri bebas termodifikasi dan inkuiri terbimbing mahasiswa pendidikan fisika dikategorikan dalam kategori sedang. Selanjutnya, untuk statistik inferensial menyatakan bahwa $t_{\text {hitung }}$ $>t_{\text {tabel }}$ yaitu 3,12 >1,98 dengan $\mathrm{H}_{0}$ ditolak. Hal ini menunjukkan bahwa terdapat perbedaan pemahaman ekstrapolasi antara motode pembelajaran inkuiri bebas termodifikasi dengan inkuiri terbimbing mahasiswa pendidikan fisika UIN Alauddin Makassar.
\end{abstract}


Kata kunci : pemahaman ekstrapolasi, inkuiri terbimbing, inkuiri bebas termodifikasi.

Pendidikan memiliki hubungan erat dengan transfer of knowladge, Sebab itu kompetensi profesional dosen atau guru sangat banyak diperoleh dalam proses perkuliahan. Salah satu mata kuliah yang memerlukan pendalaman yang baik adalah mata kuliah fisika dasar, yang merupakan salah satu mata kuliah yang akan memberikan bekal yang lebih dalam proses peningkatan profesional guru terutama pada kompetensi profesional guru fisika pada khusunya. Mata kuliah fisika dasar pada dasarnya sangat berkaitan dengan kerja laboratorium.

Motode inquiry dikembangkan dengan beberapa motode antara lain inkuiri bebas atau free inquiry, inquiry terbimbing atau guided inquiry atau inkuiri terbimbing, dan modified free inquiry atau inkuiri bebas termodifikasi. Dalam pendekatan inkuiri bebas mahasiswa atau peserta didik dibebaskan untuk mencari masalah dan kemudian menyelesaikannya tanpa ada bimbingan. Untuk inkuiri terbimbing dosen memberikan petunjuk penyelesaikan/permasalahan yang cukup luas kepada mahasiswa. Sedangkan untuk inkuiri bebas termodifikasi dosen hanya memberikan permasalahan dan kemudian mahasiswa diberikan keleluasaan untuk melakukan pengamatan, eksplorasi, dan juga penelitiannya. Berdasarkan hasil penelitian Schlenker dalam Trianto (2007: 136) menunjukkan bahwa latihan inkuiri dapat meningkatkan pemahaman sains, produktif dalam berpikir kreatif dan siswa menjadi terampil dalam memperoleh dan menganalisis informasi.

Dalam kamus besar bahasa Inggris (Oxford English Dictionary), kata inquiry adalah kata kerja dari enquire yang berarti investigate yaitu menyelidiki, meneliti, mengusut, memeriksa. Banyak yang beranggapan bahwa inkuiri merupakan suatu metode yang hanya dapat dilakukan oleh para ilmuan dalam melaksanakan suatu penyelidikan. Anggapan ini memberikan suatu pemikiran bahwa metode inkuiri tidak dapat diterapkan dalam proses pembelajaran. Namun, di dalam Standar Nasional Pendidikan Sains Amerika Serikat
(National Science Education Standard, NSES), terdapat sebuah pernyataan mengenai inkuiri (Flick and Lederman, 2006: 5), yaitu:

"Inquiry refers to the diverse ways in which scientists study the natural world and propose explanations based on the evidence derived from their work. Inquiry also refers to the activities of students in which they develop knowledge and understanding of scientific ideas, as well as an understanding of how scientists study the natural world".

Pernyataan di atas menjelaskan bahwa selain digunakan oleh para ilmuan, inkuiri juga berkenaan dengan aktivitas siswa atau mahasiswa, siswa atau mahasiswa mengembangkan pengetahuan dan pemahaman mengenai gagasan ilmiah, seperti halnya para ilmuan yang mempelajari fenomena alam untuk mengetahui sifat-sifatnya. Berdasarkan pernyataan NSES (Nasional Science Education Standart) ini, maka dapat disimpulkan bahwa inkuiri bukan hanya dilakukan oleh para ilmuan tetapi dapat juga diterapkan dalam proses pembelajaran dan menjadi salah satu solusi untuk memacu keaktifan peserta didik dalam proses pembelajaran.

Pembelajaran menggunakan metode inkuiri pertama kali dikembangkan oleh Richard Suchman yang menginginkan bahwa siswa atau mahasiswa bertanya mengapa suatu peristiwa terjadi, selanjutnya mahasiswa melakukan kegiatan, mengumpulkan data dan menganalisis data, sampai kegiatan akhir mahasiswa menemukan jawaban dari pertanyaan itu.

Adapun tahapan dan prosedur pelaksanaan inkuiri yang dikemukakan oleh Bruner (Tabrani R, 1989: 177), yaitu :

a. Pemberian rangsangan (stimulation)

Dosen atau guru memulai pembelajaran dengan mengajukan pertanyaan, mengajukan persoalan, menganjurkan mahasiswa membaca buku, dan aktivitas lainnya yang mengarah pada persiapan pemecahan masalah.

b. Pernyataan atau identifikasi masalah (problem statement) 
Dosen atau guru memberi kesempatan kepada mahasiswa untuk mengidentifikasi masalah sebanyak mungkin yang relevan dengan materi pelajaran, kemudian salah satunya dipilih dan dirumuskan dalam bentuk hipotesis (jawaban sementara atas pertanyaan masalah).

c. Pengumpulan data (data collection)

Dosen atau guru memberi kesempatan kepada mahasiswa untuk mengumpulkan informasi sebanyak-banyaknya yang relevan untuk membuktikan benar tidaknya hipotesis.

d. Pengolahan data (data processing)

Semua informasi (hasil pengamatan, bacaan) tersebut diolah, diacak, diklasifikasikan, ditabulasikan dan jika diperlukan dihitung dengan cara tertentu serta ditafsirkan dengan taraf kepercayaan tertentu.

e. Verifikasi (verification)

Mahasiswa melakukan pemeriksaan secara cermat untuk membuktikan benar atau tidaknya hipotesis yang ditetapkan dan dihubungkan dengan hasil pengolahan data.

f. Generalisasi (generalization) Menarik sebuah kesimpulan yang dapat dijadikan prinsip umum dan berlaku untuk semua kejadian yang sama, dengan memperhatikan hasil verifikasi.

Kuhlthau (2007: 1-2) menjelaskan bahwa pelaksanaan pembelajaran dengan inquiry tanpa adanya arahan atau bimbingan maka akan mengakibatkan kekacauan pada proses pembelajaran tersebut. Maka dalam penerapannya, peserta didik harus mendapatkan arahan dari guru atau pendidik, yang kemudian diistilahkan dengan motode guided inquiry. Motode guided inquiry adalah suatu motode seorang guru untuk membimbing peserta didik dalam membangun pengetahuan dan pemahamannya melalui suatu penyelidikan yang dirancang secara hati-hati dan tetap dalam pengawasan.

Pembelajaran inkuiri terbimbing merupakan motode inkuiri yang diorganisir lebih terstruktur, dimana dosen atau guru mengendalikan keseluruhan proses interaksi dan menjelaskan prosedur penelitian yang harus ditempuh mahasiswa. Pada motode ini tingkat bimbingan dosen cukup besar di dalam proses inkuiri yang dilakukan oleh mahasiswa. Dosen atau guru berperan menciptakan situasi bermasalah, menyediakan prosedur inkuiri, memberikan respon terhadap inkuiri dan menyediakan fasilitas diskusi mahasiswa.

Motode inkuiri bebas termodifikasi pada prinsipnya hampir sama dengan motode inkuiri bebas, tetapi dosen yang menyiapkan masalah bagi mahasiswa. Dosen hanya memberikan permasalahan, kemudian mahasiswa diundang untuk memecahkan masalah tersebut melalui pengamatan, eksplorasi, atau melalui prosedur penelitian untuk memperoleh jawabannya. Dalam hal ini, mahasiswa diberi kesempatan yang luas untuk memecahkan masalah yang telah ditentukan melalui inisiatif dan caranya sendiri.

Peserta didik diharuskan merencanakan garis besar prosedur penelitian atau eksperimen yang digunakan untuk membuat rancangan dan melakukan eksperimen. Guru hanya menyajikan masalah dan menyediakan bahan dan alat yang diperlukan Peserta didik untuk memecahkan masalah tersebut. Selanjutnya mahasiswa diberi kebebasan yang cukup luas untuk memecahkan masalah.

Dosen merupakan nara sumber (resource person) yang tugasnya hanya memberikan bantuan yang diperlukan untuk menjamin bahwa Peserta didiknya tidak menjadi frustasi atau gagal. Bantuan yang diberikan harus berupa pertanyaan-pertanyaan yang memungkinkan Peserta didik dapat berpikir dan menemukan cara-cara penelitian yang tepat. dosen mengajukan pertanyaan yang dapat membantu Peserta didik mengerti arah pemecahan masalah, bukan menjelaskan apa yang harus dilakukan.

Salah satu aspek pada ranah kognitif yang dikemukakan oleh Benyamin S. Bloom adalah aspek pemahaman (comprehension). Bloom (1956: 89) menjelaskan tentang definisi dari pemahaman:

"Comprehension that is when students are confronted with a communication, they are expected to know what is being communicated and to be able to make some use of the material or ideas contained in it. The communication may be in oral or written form, in verbal or symbolic form."

Pernyataan tersebut memiliki makna bahwa, pemahaman adalah ketika peserta didik 
atau mahasiswa yang dihadapkan pada suatu komunikasi, mereka diharapkan mengetahui apa yang sedang dikomunikasikan dan dapat menggunakan ide-ide yang terkandung dalam komunikasi tersebut.

Pemahaman atau comprehension dapat juga diartikan menguasai sesuatu dengan pikiran. Karena itu memahami berarti harus mengerti secara mental makna dan filosofinya, maksud dan implikasi serta aplikasi-aplikasinya, sehingga menyebabkan peserta didik dapat memahami suatu situasi. Hal ini sangat penting bagi peserta didik yang belajar. Comprehension atau pemahaman, memiliki arti yang sangat mendasar yang meletakkan bagian-bagian belajar pada proporsinya. Tanpa itu, skill pengetahuan dan sikap tidak bermakna (Sardiman, 2012: 42).

Menurut Bloom (1956: 91-95), pemahaman dapat dibedakan menjadi tiga aspek, salah satunya yaitu pemahaman ekstrapolasi. Kemampuan pemahaman ekstrapolasi menuntut kemampuan intelektual yang lebih tinggi, seperti membuat telaahan tentang kemungkinan apa yang akan berlaku. Pemahaman ekstrapolasi (kemampuan meramalkan) adalah kemampuan untuk meramalkan kecenderungan yang ada menurut data tertentu dengan mengutarakan konsekuensi dan implikasi yang sejalan dengan kondisi yang digambarkan. Dalam proses pembelajaran, pemahaman ekstrapolasi terdiri atas beberapa indikator pencapaian yaitu:

a. Kemampuan menggambarkan, menaksir atau memprediksi akibat dari tindakan tertentu.

b. Keterampilan meramalkan kecenderungan yang akan terjadi.

c. Kemampuan menyisipkan satu data dalam sekumpulan data dilihat dari kecenderungannya.

Berdasarkan paparan di atas maka peneliti tertarik untuk menerapkan motode inkuiri pada mata kuliah fisika dasar 2. Pada mata kuliah fisika dasar 1 mahasiswa telah melakukan praktikum fisika dasar 1 , sehingga syarat untuk melakukan eksperimen untuk fisika dasar 2 telah terpenuhi yaitu mahasiswa mampu menggunakan alat ukur dan mampu melakukan pengukuran. Dari paparan inilah maka peneliti mengambil judul "Perbandingan Pemahaman Ekstrapolasi antara Motode Pembelajaran Inkuiri Terbimbing dan Inkuiri Bebas
Termodifikasi Mahasiswa Pendidikan Fisika UIN Alauddin Makassar" dengan tujuan penelitian yaitu :

a. Untuk mendeskripsikan pemahamana ekstrapolasi dengan menggunakan motode pembelajaran inkuiri terbimbing mahasiswa Jurusan Pendidikan Fisika UIN Alauddin Makassar

b. Untuk mendeskripsikan pemahaman ekstrapolasi dengan menggunakan motode pembelajaran inkuiri bebas termodifikasi mahasiswa Jurusan Pendidikan Fisika UIN Alauddin Makassar

c. Untuk menganalisis perbedaan pemahaman ekstrapolasi dengan menggunakan motode pembelajaran inkuiri bebas termodifikasi dengan inkuiri terbimbing mahasiswa Jurusan Pendidikan Fisika UIN Alauddin Makassar.

\section{MOTODE PENELITIAN}

Penelitian ini merupakan penelitian true eksperimen dengan merandom semua kelas yang menjadi populasi untuk mendapatkan dua kelas untuk kelas inkuiri terbimbing dan kelas inkuiri bebas termodifikasi. selanjutnya kedua kelas tersebut dirandom untuk menentukan kelas yang diajar dengan menggunakan motode inkuiri terbimbing dan kelas yang diajar dengan menggunakan motode inkuiri bebas termodifikasi. Kelas eksperimen 2 diberikan motode pembelajaran inkuiri bebas termodifikasi dan kelas eksperimen 1 diberikan motode pembelajaran inkuiri terbimbing.

Seluruh mahasiswa pendidikan fisika Fakultas Tarbiyah dan Keguruan UIN Alauddin Makassar semister 2 merupakan populasi dari penelitian ini. populasi terdiri atas 3 kelas terdiri dari 34 orang kelas A, 33 orang kelas B dan 39 orang kelas C. Total populasi pada penelitian ini 106 orang.

Semua populasi mendapat peluang menjadi sampel, kelas adalah bagian yang dirandom dengan pertimbangan bahwa tidak memungkinkan merandom sampel karena jika sampel yang dirandom maka akan dibuat kelas baru, dan hal ini tidak diijinkan oleh penentu kebijakan di Jurusan Pendidikan Fisika UIN Alauddin Makassar. 
Instrumen yang digunakan yaitu instrumen tes pemahaman ekstrapolasi. Instrumen ini digunakan untuk mengukur pemahaman konsep ekstrapolasi mahasiswa setelah penggunaan motode pembelajaran. Tes ini disusun dalam tes tertulis dalam bentuk pilihan ganda dengan indikator pemahaman dari pemahaman konsep ekstrapolasi. Pilihan jawaban terdiri atas 5 item pilihan untuk setiap butirnya .Setiap soal memiliki satu pilihan jawaban yang benar, dan jika mahasiswa memilih jawaban yang benar maka mahasiswa mendapatkan skor 1 dan skor 0 jika mahasiswa menjawab pertanyaan dengan salah.
Analisis data yang digunakan yaitu statisik deskriptif dan statistik inferensial dengan menggunakan uji $\mathrm{T}-2$ sampel independen.

\section{HASIL DAN PEMBAHASAN}

\section{Hasil Statistik Deskriptif}

Data distribusi frekuensi kategorisasi skor pemahaman ekstrapolasi kelas dengan menggunakan motode inkuiri bebas termodifikasi dan inkuiri terbimbing digambarkan pada tabel 1 dan histogram kategorisasi pada gambar 1:

Tabel 1. Rekapitulasi Skor Pemahaman Ekstrapolasi Pada Kelas Dengan Menggunakan Metode Inkuiri Bebas Termodifikasi dan Metode Inkuiri Terbimbing.

\begin{tabular}{lcc}
\hline Hasil Skor Hasil Belajar Fisika & Kelas Inkuiri Bebas Termodifikasi & Kelas Inkuiri Terbimbing \\
\hline Jumlah Sampel & 33 & 34 \\
Rata-Rata & 5,94 & 4,94 \\
Standar Deviasi & 1,08 & 1,52 \\
Skor Maksimum & 9 & 8 \\
Skor Minimum & 3 & 2 \\
Skor Maksimum Ideal & 10 & 10 \\
Skor Minimum Ideal & 0 & 0 \\
\hline
\end{tabular}

Tabel 1 menunjukkan bahwa, pada kelas dengan menggunakan metode inkuiri bebas termodifikasi skor pemahaman ekstrapolasi diperoleh skor rata-rata 5,94, standar deviasi 1,08, skor maksimum 9, skor minimum 3. Sedangkan pada kelas dengan menggunakan metode inkuiri terbimbing diperoleh skor rata- rata 4,94, standar deviasi 1,52 , skor maksimum 8 , skor minimum 2 .

Adapun hasil yang diperoleh berdasarkan tingkat kategori pemahaman konsep fisika mahasiswa pada kelas dengan menggunakan metode inkuiri bebas termodifikasi dan inkuiri terbimbing terdapat pada Tabel 2.

Tabel 2 : Interval Kategori Skor Pemahaman Konsep Fisika Kelas Dengan Menggunakan Metode Inkuiri Bebas Termodifikasi dan Metode Inkuiri Terbimbing.

\begin{tabular}{cccccl}
\hline \multirow{2}{*}{ Interval } & \multicolumn{3}{c}{ Frekuensi } & \multicolumn{3}{c}{ Persentase (\%) } & \multirow{2}{*}{ Klasifikasi } \\
\cline { 2 - 5 } & $\begin{array}{c}\text { Inkuiri Bebas } \\
\text { Termodifikasi }\end{array}$ & $\begin{array}{c}\text { Inkuiri } \\
\text { Terbimbing }\end{array}$ & $\begin{array}{c}\text { Inkuiri Bebas } \\
\text { Termodifikasi }\end{array}$ & $\begin{array}{c}\text { Inkuiri } \\
\text { Terbimbing }\end{array}$ & \\
\hline $9-10$ & 0 & 0 & 0,0 & 0,0 & Sangat baik \\
$7-8$ & 10 & 6 & 30,3 & 17,7 & Baik \\
$5-6$ & 17 & 15 & 51,5 & 44,1 & Sedang \\
$3-4$ & 6 & 12 & 18,2 & 35,3 & Kurang \\
$0-2$ & 0 & 1 & 0,0 & 2,9 & Sangat kurang \\
\hline
\end{tabular}




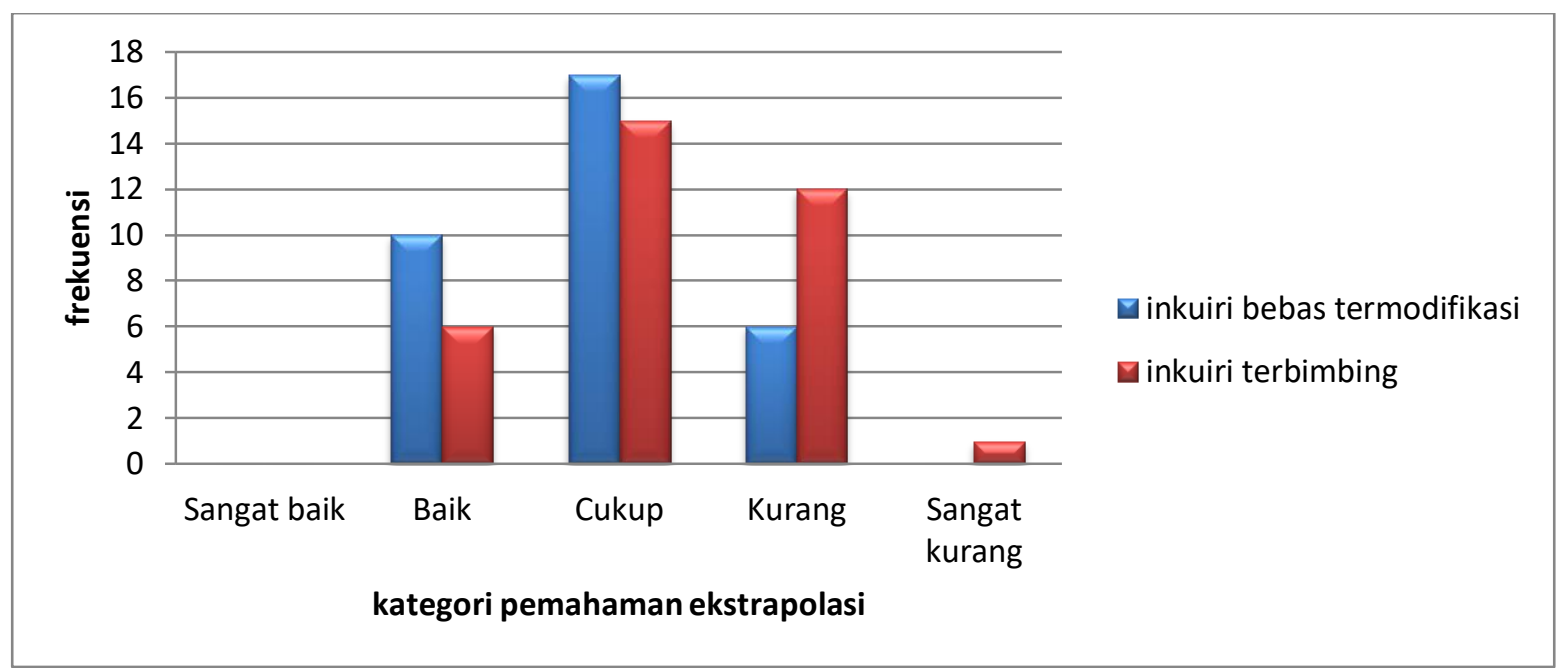

Gambar 1 : Histogram Kategori Skor Pemahaman Interpretasi

Berdasarkan Tabel 1 dan Gambar 1, dengan jumlah 33 mahasiswa pada kelompok yang menggunakan metode inkuiri bebas termodifikasi dan 34 mahasiswa pada kelompok yang menggunakan inkuiri terbimbing, dapat ditunjukkan bahwa jumlah mahasiswa yang memiliki pemahaman ekstrapolasi dengan menggunakan metode inkuiri bebas termodifikasi dan inkuiri terbimbing berturutturut, pada kategori sangat kurang sebanyak 0 $(0,0 \%)$ dan $1(2,9 \%)$ orang, kategori kurang 6 $(18,2 \%)$ dan $12(35,3 \%)$ orang, kategori sedang $17(51,5 \%)$ dan $15(44,1 \%)$ orang, kategori baik $10(30,3 \%)$ dan $6(17,7 \%)$ orang.

Berdasarkan data diatas maka dapat disimpulkan bahwa pemahaman ekstrapolasi mahasiswa dengan menggunakan inkuiri bebas termodifikasi lebih tinggi dibandingkan dengan menggunakan inkuiri terbimbing. Hal ini ditunjukkan pada kategori sangat kurang dan kurang, frekuensi mahasiswa pada kelompok yang menggunakan inkuiri bebas termodifikasi lebih rendah dibandingkan kelompok mahasiswa yang menggunakan metode inkuiri terbimbing. Sedangkan pada kategori sedang dan baik sebaliknya frekuensi kelompok mahasiswa yang menggunakan metode pembelajaran inkuiri bebas termodifikasi lebih tinggi dibandingkan frekuensi mahasiswa pada kelompok yang menggunakan metode pembelajaran inkuiri terbimbing.

\section{Hasil Statistik Inferensial}

Kriteria pengujian $\mathrm{H}_{0}$ terima jika $t_{\left(1-\frac{1}{2} \alpha\right)\left(n_{1}+n_{2}-2\right)}<t<t_{\left(1-\frac{1}{2} \alpha\right)\left(n_{1}+n_{2}-2\right)}$ dan untuk harga $\mathrm{t}$ lainnya $\mathrm{H}_{0}$ ditolak dengan $\mathrm{t}_{0,95}=1,98$. Berdasarkan hasil perhitungan di atas $t_{\text {test }}$ diperoleh $t_{\text {hitung }}>t_{\text {tabel }}(3,12>1,98)$ maka $\mathrm{H}_{0}$ ditolak dan $\mathrm{H}_{1}$ diterima. Artinya terdapat perbedaan pemahaman ekstrapolasi antara mahasiswa yang belajar dengan menggunakan metode inkuiri bebes termodifikasi dan inkuiri terbimbimbing, dalam penelitian ini diperoleh bahwa pemahaman ekstrapolasi mahasiswa yang belajar dengan menggunakan metode inkuiri bebas termodifikasi lebih tinggi dibandingkan dengan mahasiswa yang belajar dengan menggunakan metode inkuiri terbimbing.

Hasil penelitian ini sejalan dengan penelitian yang pernah dilakukan oleh Khanafiyah,S(2010: E7-E14) yang menyatakan bahwa dengan menggunakan pendekatan inkuiri bebas termodifikasi dapat meningkatkan psikomotorik, kreativitas dan kemampuan mahasiswa memahami materi gelombang meningkat secara signifikan.yang membedakan yaitu pada penelitian ini yang ingin dilihat adalah pemahaman ekstrapolasi.

Kemampuan pemahaman ekstrapolasi mencakup pemikiran atau prediksi yang dilandasi oleh pemahaman kecendrungan atau kondisi yang dijelaskan dalam komunikasi ataupun data. Situasi ini memungkinkan melibatkan pembuatan kesimpulan sehubungan 
dengan implikasi, konsekuensi akibat dan efek sesuai dengan kondisi yang dijalaskan dalam komunikasi atau data. kemampuan ekstrapolasi berkembang dengan baik jika mahasiswa menemukan sendiri kesimpulan dari konsep yang telah dikonstruk oleh mahasiswa, karena untuk memprediksi suatu kecendrungan yang akan terjadi harus mempu terlebih dahulu mengetahui konsep dari materi yang dipelajari. Dengan melihat bahwa metode inkuiri bebas termodifikasi mahasiswa cenderung lebih mandiri dalam menyelesaikan masalah yang diperolah dibandingkan dengan metode inkuiri terbimbing yang masih mendapatkan bimbingan yang lebih banyak dibandingkan inkuiri bebas termodifikasi. Sehingga mahasiswa yang diajar dengan menggunakan metode inkuiri bebas termodifikasi lebih baik dalam memprediksi data yang diberikan berdasarkan kecenderungannya.

Berdasarkan hal ini maka dapat disimpulkan bahwa pemahaman ekstrapolasi kelompok mahasiswa yang diajar dengan menggunakan metode pembelajaran inkuiri bebas termodifikasi lebih baik dibandingkan dengan metode pembelajaran inkuiri terbimbing.

4. yang diajar dengan inkuiri terbimbing.

\section{DAFTAR PUSTAKA}

Anderson dan Krathwohl. 2010. Kerangka Landasan Untuk Pembelajaran, Pengajaran, Dan Asesmen (Edisi Terjemahan). Yogyakarta: Pustaka Belajar.

Aryani, A. 2012. Pembelajaran IPA dengan Inkuiri Bebas Termodifikasi Menggunakan Lab Riil dan Virtual Ditinjau Dari Kemampuan Berpikir dan Gaya Belajar Siswa. Jurnal inkuiri, (online), vol. 1, No. 2, (http://jurnal.pasca.uns.ac.id).

Bloom, B. S. 1956. Taxonomy of Educational Objectives: The Classification of Educational Goals. New York: McKay.

Giancoli, Douglas C. 2001. Fisika Jilid I (terjemahan). Jakarta : Erlangga

Khanafiyah, S. 2010. Penerapan Pendekatan Modified Free Inquiry Sebagai Upaya Meningkatkan Kreativitas Mahasiswa Calon Guru Dalam Mengembangkan Jenis Eksperimen dan Pemahaman Terhadap Materi

\section{KESIMPULAN}

Berdasarkan hasil penetilian dan pembahasan yang telah dipaparkan pada bab sebelumnya, maka dapat ditarik kesimpulan sebagai berikut :

1. Pemahaman konsep ekstrapolasi fisika melalui motode pembelajaran inkuiri terbimbing mahasiswa Jurusan Pendidikan Fisika UIN Alauddin Makassar berada pada kategori sedang.

2. Pemahaman konsep ekstrapolasi fisika melalui motode pembelajaran inkuiri bebas termodifikasi mahasiswa Jurusan Pendidikan Fisika UIN Alauddin Makassar berada pada kategori sedang.

3. Terdapat perbedaan pemahaman ekstrapolasi antara kelompok mahasiswa yang diajar dengan menggunakan inkuiri bebas termodifikasi dengan kelompok mahasiswa

Fisika. Jurnal Berkala Fisika. Vol 13: hal. E7 - E14. 2010.

Kuhlthau, C.C., Maniotes, L.K., \& Caspari, A.K. 2007. Guided Inquiry: Learning in the $21^{\text {st }}$ Century. USA: British Library Cataloguing.

Kuswana, W.S. 2012. Taksonomi Kognitif: Perkembangan Ragam Berpikir. Bandung: Remaja Rosdakarya.

Lawson, Anton E. 1993. Inductive-deductive versus hypothetico-deductive reasoning. Journal of Research in Science Teaching. Hal. 613-614.

Maliyah, Ninik. 2012. Pembelajaran Fisika dengan Inkuiri Terbimbing Melalui Motode Eksperimen dan Demonstrasi Diskusi Ditinjau Dari Kemampuan Matematika dan Kemampuan Verbal Siswa. Jurnal inkuiri, (online), vol. 1, No. 3, (http://jurnal.pasca.uns.ac.id). 
Karst : Jurnal Pendidikan Fisika dan Terapannya Volume 3 | Nomor 2 | 61 p-ISSN: 2622-9641 e-ISSN: 2655-1276

Minner, Daphne et al. 2009. Inquiry-Based Science Instruction-What Is It and Does It Matter? Results from a Research Synthesis Years 1984 to 2002. Journal of Research in Science Teaching. 21 September 2009.

Mudjiman, Haris. 2006. Belajar Mandiri. Surakarta : UNS Press.

Purwanto. 2011. Statistika Untuk Penelitian. Yogyakarta: Pustaka Belajar.

Rahayu, Sri. 2011. Pembelajaran Biologi dengan Motode inkuiri terbimbing dan Inkuiri Bebas Termodifikasi Ditinjau Dari Motivasi
Berprestasi dan Sikap Ilmiah Siswa. Tesis (online): Universitas Sebelas Maret.

Sardiman. 2012. Interaksi dan Motivasi Belajar Mengajar. Jakarta: Raja Grafindo Persada.

Sudjana. 2005. Motode Statistika. Bandung: Tarsito.

Suparno, Paul. 1997. Filsafat Konstruktivisme Dalam Pendidikan. Yogyakarta: Kanisius.

Trianto. 2007. Motode-Motode Pembelajaran Inovatif Berorientasi Konstruktivistik. Jakarta: Prestasi Pustaka Publisher. 